\title{
Microwave dielectric properties of mineral sillimanite obtained by conventional and cold sintering process
}

I.J.Induja, M.T.Sebastian

\section{Abstract}

The sillimanite (Al2SiO5) mineral has been sintered by conventional ceramic route and by cold sintering methods. The mineral has very poor sinterability and transformed to mullite on sintering above $1525^{\circ} \mathrm{C}$. The dielectric properties of sillimanite mineral $\left(\mathrm{Al}_{2} \mathrm{SiO}_{5}\right)$ are investigated at radio and microwave frequency ranges. The mineral sintered at $1525^{\circ} \mathrm{C}$ has low $\varepsilon_{\mathrm{r}}$ of 4.71 and tan $\delta$ of 0.002 at $1 \mathrm{MHz}$ and at microwave frequency $\varepsilon_{r}=4.43, \mathrm{Q}_{u} \times \mathrm{f}=41,800 \mathrm{GHz}$ with $\tau_{\mathrm{f}}=-17 \mathrm{ppm} /{ }^{\circ} \mathrm{C}$. The sintering aid used for cold sintering $\mathrm{Al}_{2} \mathrm{SiO}_{5}$ is sodium chloride $(\mathrm{NaCl})$. The $\mathrm{Al}_{2} \mathrm{SiO}_{5} \mathrm{NaCl}$ composite was cold sintered at $120^{\circ} \mathrm{C}$. XRD analysis of the composite revealed that there is no additional phase apart from $\mathrm{Al}_{2} \mathrm{SiO}_{5}$ and $\mathrm{NaCl}$. The densification of the $\mathrm{Al}_{2} \mathrm{SiO}_{5} \mathrm{NaCl}$ composite was confirmed by using microstructure analysis. The $\mathrm{Al}_{2} \mathrm{SiO}_{5} \mathrm{NaCl}$ composite has $\varepsilon_{\mathrm{r}}$ of 5.37 and $\tan \delta$ of 0.005 at $1 \mathrm{MHz}$ whereas at microwave frequency it has $\varepsilon_{\mathrm{r}}=4.52$, Qux $\mathrm{f}=22,350 \mathrm{GHz}$ with $\tau_{f}=-24 \mathrm{ppm} /{ }^{\circ} \mathrm{C}$. The cold sintered $\mathrm{NaCl}$ has $\varepsilon_{r}=5.2$, Qux $\mathrm{f}=12,000 \mathrm{GHz}$ with $\tau_{\mathrm{f}}=-36 \mathrm{ppm} /{ }^{\circ} \mathrm{C}$.

\section{Introduction}

Microwave dielectric materials conquer today's wireless communication industry by providing a wide variety of applications such as broadcasting satellites, cellular phone, global positioning systems etc. [1]. New microwave substrate materials with low relative permittivity and high performance are desired for high speed communication devices [2]. For microwave substrate applications the dielectric materials should possess low dielectric constant $\left(\varepsilon_{r}\right)$, low loss(tan $\left.\delta\right)$, low temperature coefficient of permittivity $\left(\tau_{\varepsilon}\right)$, high thermal conductivity and low coefficient of thermal expansion [3]. Low $\varepsilon_{r}$ materials offer the advantage of fast signal propagation $[3,4]$. Sillimanite $\left(\mathrm{Al}_{2} \mathrm{SiO}_{5}\right)$ is a naturally occurring alumino silicate polymorph which is obtained as a by product during the extraction of rare earths from beach sand minerals $[5,6]$. The most wellknown alumino-silicate polymorphsare sillimanite $\left(\mathrm{Al}_{2} \mathrm{SiO}_{5}\right)$, andalusite $\left(\mathrm{Al}_{2} \mathrm{SiO}_{5}\right)$ and kyanite $\left(\mathrm{Al}_{2} \mathrm{SiO}_{5}\right)[7,8]$. In 1928 , Taylor first resolved the crystal structure of sillimanite while the cell dimensions and space group was determined by Mark and Rosband in 1926 [9,10].Sillimanite decomposes into mullite (Al6Si2O13) and cristobalite $(\mathrm{SiO} 2)$ on heating between $1500^{\circ} \mathrm{Cand} 1650^{\circ} \mathrm{C}[11,12]$. The decomposition temperature may differ depending on the region of its occurrence. Sillimanite and mullite are compounds of alumino silicates with $\mathrm{Si}-\mathrm{Al}$ tetrahedral chains[13]. The main applications of $\mathrm{Al}_{2} \mathrm{SiO}_{5}$ are in the fabrication of high tension insulators, spark plugs, glass furnaces, combustion chambers etc [14].

Recently Kahari et al. reported $[15,16]$ a novel method toprepare $\mathrm{Li}_{2} \mathrm{MoO}_{4}$ ceramics at room temperature by moistening the water soluble $\mathrm{Li}_{2} \mathrm{MoO}_{4}$ powder using deionized water and pressing the sample at about 130 $\mathrm{MPa}$. The samples were then dried at room temperature or at $120^{\circ} \mathrm{C}$. There was no appreciable difference in the sintered density of the samples dried at room temperature, dried at $120^{\circ} \mathrm{C}$ or sintered at $540^{\circ} \mathrm{C}$. The amount of water in the pressed samples was about 2-3 wt\% before drying or sintering. It is believed that the densification of the samples occurred during pressing. X-ray diffraction study showed that the crystal structure remains the same and water did not react to form any hydrates. The room temperature dried samples showed a $Q_{u} \times f$ value slightly less than that prepared by conventional sintering method and is attributed to the presence of small amount of residual water. It was found [16] that ceramic powder particle size has great influence on preparation; densification and dielectric properties. Larger particles are 
advantageous in fabricating $\mathrm{Li}_{2} \mathrm{MoO}_{4}$ ceramics by moistening and pressing method. Smaller particles lead to clay like clusters leading to non-uniform densification, warpage and cracking. Kahari et al. [17] tailored the dielectric properties by adding $\mathrm{TiO}_{2}$ and $\mathrm{BaTiO}_{3}$ in $\mathrm{Li}_{2} \mathrm{MoO}_{4}$ with optimized room temperature preparation method. More recently Randall and co-workers have done extensive work [18-28] on room temperature or sintering below $200^{\circ} \mathrm{C}$ by the same technique and introduced the term cold sintering process (CSP). CSP is primarily based on the solid particle rearrangement with the help of liquid phase followed by densification by dissolution-precipitation [19]. The temperature, pressure, the particle size of the ceramic powder, amount of solvent added are the key factors that control the CSP process [19]. CSP technique has been utilized for achieving dense ceramic, ceramic-polymer composites at temperature less than $200^{\circ} \mathrm{C}$. Simplicity as well as energy saving are the attractive features of CSP process $[15,23]$. Owing to the low temperature sintering, CSP method offers the advantage of integrating polymers with ceramics. The CSP method was successfully applied to $\mathrm{NaCl}$, alkali molybdates, $\mathrm{KH}_{2} \mathrm{PO}_{4}, \mathrm{NaNO}_{2}$, zirconia, $\mathrm{ZnO}, \mathrm{BaTiO}_{3}$ and $\mathrm{V}_{2} \mathrm{O}_{5}$ [22,25-28]. The possibility of incorporating ceramics with polymers in single step sintering using the emerging CSP method for the study of $\mathrm{Li}_{2} \mathrm{MoO}_{4}-\left(-\mathrm{CF}_{2}-\right) \mathrm{n}(\mathrm{PTFE})$, electrolyte $\mathrm{Li}_{1.5} \mathrm{Al}_{0.5} \mathrm{Ge}_{1.5}\left(\mathrm{PO}_{4}\right)_{3}\left(-\mathrm{CH}_{2} \mathrm{CF}_{2}\right) \times\left[\mathrm{CH}_{2} \mathrm{CF}\left(\mathrm{CF}_{3}\right) y(\mathrm{PVDF}-\mathrm{HFP})\right.$ and semiconductor $\mathrm{V}_{2} \mathrm{O}_{5}$-poly(3,4-ethylenedioxythiophene)polystyrene sulfonate(PEDOT:PSS) composites was also exploited [20]. Baker et al. fabricated monolithic capacitor using lithium molybdenum oxide ceramic material by CSP method [24]. In the present paper we report the microwave dielectric properties of sillimanite mineral sintered by the conventional solid state method and by cold sintering process using $\mathrm{NaCl}$ as sintering aid.

\section{Experimental}

The mineral sillimanite obtained from Indian Rare Earths Lim-ited (IRE) was planetary ball milled for $6 \mathrm{~h}$ using distilled water medium in order to reduce its particle size. The average particle size of the $\mathrm{Al}_{2} \mathrm{SiO}_{5}$ after ball milling was found out using dynamic lights cattering instrument (Malvern Zetasizer, Nano-ZS, UK). The slurrywas dried at $100^{\circ} \mathrm{C}$. The dried $\mathrm{Al}_{2} \mathrm{SiO}_{5}$ powder was ground well and polyvinyl alcohol (PVA) was added prior to pelletizing the bulk sample. The bulk $\mathrm{Al}_{2} \mathrm{SiO}_{5}$ was sintered at $1525^{\circ} \mathrm{C}$ and the structural, micro structural analysis and dielectric studies were carried out. Sodium chloride ( $\mathrm{NaCl}$ ) from SDFCL, Mumbai, India was used for the present study. $\mathrm{NaCl}$ was moistened using deionized water and then transferred into suitable die set and hot pressed at $120^{\circ} \mathrm{C}$ by applying a pressure of $200 \mathrm{MPa}$. After several trial and errors, a 1:1 ratio (in weight\% (wt\%)) was maintained between $\mathrm{Al}_{2} \mathrm{SiO}_{5}$ and $\mathrm{NaCl}$ for cold sintering $\mathrm{Al}_{2} \mathrm{SiO}_{5}$. For preparing the composite containing $\mathrm{Al}_{2} \mathrm{SiO}_{5}-\mathrm{NaCl}$, first $\mathrm{NaCl}$ was moistened with deionized water and $\mathrm{Al}_{2} \mathrm{SiO}_{5}$ was added into it. The mixture was thoroughly mixed using deionized water to make a paste. In the present work, $4 \mathrm{wt} \%$ deionized water was added to make the paste of $\mathrm{Al}_{2} \mathrm{SiO}_{5}-\mathrm{NaCl}$ depending upon the weight of the composite taken. The paste was in semi solid form. The $\mathrm{Al}_{2} \mathrm{SiO}_{5}-\mathrm{NaCl}$ composite was then hot pressed using die set at a temperature of about $120^{\circ} \mathrm{C}(50 \mathrm{~min})$ and pressure $200 \mathrm{MPa}$. In order to remove the moisture content, the cold sintered $\mathrm{NaCl}$ and $\mathrm{Al}_{2} \mathrm{SiO}_{5}-\mathrm{NaCl}$ composite was kept in hot air oven at $120^{\circ} \mathrm{C}$ for $24 \mathrm{~h}$. The phase composition of bulk $\mathrm{Al}_{2} \mathrm{SiO}_{5}, \mathrm{Al}_{2} \mathrm{SiO}_{5}-\mathrm{NaCl}$ was studied using XRD (CuKa radiation, PANalyticalX'Pert PRO diffractometer, Netherlands). The room temperature FT-IR spectrum of cold sintered $\mathrm{Al}_{2} \mathrm{SiO}_{5} \mathrm{NaCl}$ was recorded using Agilent Technologies, 600ATR, UK using the $\mathrm{KBr}$ pellet method. The microstructure of the fractured bulk $\mathrm{Al}_{2} \mathrm{SiO}_{5}$ sintered using the conventional high temperature sintering method and $\mathrm{Al}_{2} \mathrm{SiO}_{5} \mathrm{NaCl}$ cold sintered at $120^{\circ} \mathrm{C}$ was recorded using scanning electron microscopy (JOEL-JSM5600LV, Tokyo, Japan and Zeiss, Germany). The density of the bulk $\mathrm{Al}_{2} \mathrm{SiO}_{5}$, cold sintered $\mathrm{NaCl}$ and $\mathrm{Al}_{2} \mathrm{SiO}_{5}-\mathrm{NaCl}$ composite was determined using dimensional method with the help of a digital screw gauge and weight measured using a semimicron weighing balance (Shimdazu, AUW220D, Japan). The radio frequency dielectric properties were measured by parallel plate capacitor method using an LCR meter (Hioki 3532-50 LCR Hi Tester, Japan). For radio frequency measurements of bulk $\mathrm{Al}_{2} \mathrm{SiO}_{5}$, cold sintered $\mathrm{NaCl}$ and the $\mathrm{Al}_{2} \mathrm{SiO}_{5}-\mathrm{NaCl}$ composite samples having $11 \mathrm{~mm}$ diameter and $1.5 \mathrm{~mm}$ thickness coated with silver paste on both sides were used. The microwave dielectric properties of bulk $\mathrm{Al}_{2} \mathrm{SiO}_{5}$, cold sintered $\mathrm{NaCl}$ and $\mathrm{Al}_{2} \mathrm{SiO}_{5}-\mathrm{NaCl}$ composite having 
diameter $11 \mathrm{~mm}$ and $5.4 \mathrm{~mm}$ thickness was analyzed using Hakki - Coleman method using a vector network analyzer (Agilent E5071C ENA series, AgilentTechnologies, Santa Clara, CA) in the operating range $300 \mathrm{kHz}-$ $20 \mathrm{GHz}$. The temperature coefficient of resonant frequency $\left(\tau_{f}\right)$ of bulk $\mathrm{Al}_{2} \mathrm{SiO}_{5}$, cold sintered $\mathrm{NaCl}$ and $\mathrm{Al}_{2} \mathrm{SiO}_{5}-\mathrm{NaCl}$ composite were measured using the cavity setup in the temperature range $25^{\circ} \mathrm{C}-60^{\circ} \mathrm{C}$ for every $5^{\circ}$ rises in temperature.

\section{Results and discussions}

Sillimanite is a naturally occurring mineral with orthorhombic structure having Pbnm space group symmetry. The average particle size of the $\mathrm{Al}_{2} \mathrm{SiO}_{5}$ powder was about $1 \mu \mathrm{m}$. Fig. 1 (a) shows the XRD pattern of sillimanite $\left(\mathrm{Al}_{2} \mathrm{SiO}_{5}\right)$ sintered at $1525^{\circ} \mathrm{C}$ and Fig. 1 (b) shows the XRD pattern of the bulk sintered at $1550^{\circ} \mathrm{C}$. The peaks of $\mathrm{Al}_{2} \mathrm{SiO}_{5}$ are identified and indexed using JCPDS file no.22-0018, mullite $\left(\mathrm{Al}_{6} \mathrm{Si}_{2} \mathrm{O}_{13}\right)$ using $15-0776$ and the peaks of cristobalite $\left(\mathrm{SiO}_{2}\right)$ is identified and indexed using JCPDS file no. 85 - 0621. Asevident from the XRD; the maximum temperature that the mineral sillimanite can be sintered is limited up to $1525^{\circ} \mathrm{C}$. It may be noted that sillimanite mineral often contains a small amount of quartz $\left(\mathrm{SiO}_{2}\right)$ which on heat treatment at high temperatures changes into cristobalite form. At $1550^{\circ} \mathrm{C}$, sillimanite decomposes into mullite $\left(\mathrm{Al}_{6} \mathrm{Si}_{2} \mathrm{O}_{13}\right)$ and excess silica as glass or cristobalite according to the reaction given in (1) [29]. Even though the crystal structure of sillimanite and mullite are identical (both are orthorhombic) and further more the diffraction patterns of both of them are also similar. However, there are some characteristic diffraction peaks that distinct them [6].

$$
3 \mathrm{Al}_{2} \mathrm{SiO}_{5} \rightarrow \mathrm{Al}_{6} \mathrm{Si}_{2} \mathrm{O}_{13}+\mathrm{SiO}_{2}
$$

(sillimanite) (mullite) (cristobalite)

The microstructure of the fractured surface of sillimanite $\left(\mathrm{Al}_{2} \mathrm{SiO}_{5}\right)$ sintered using the conventional solid state ceramic method at $1525^{\circ} \mathrm{C}$ is shown in Fig. 1 (c). The grains of $\mathrm{Al}_{2} \mathrm{SiO}_{5}$ areclearly visible in the microstructure. The microstructure depicts the fact that sillimanite $\left(\mathrm{Al}_{2} \mathrm{SiO}_{5}\right)$ consists of particles of polygonal shape having non-uniform size. The poor densification of the bulk $\mathrm{Al}_{2} \mathrm{SiO}_{5}$ is also evident from the microstructure. The variation of the radio frequency dielectric properties of bulk $\mathrm{Al}_{2} \mathrm{SiO}_{5}$ sintered using the conventional ceramic route at $1525^{\circ} \mathrm{Cis}$ shown in Fig. 2. The $\varepsilon_{r}$ and tan $\delta$ at $1 \mathrm{MHz}$ of bulk sillimanite $\left(\mathrm{Al}_{2} \mathrm{SiO}_{5}\right)$ sintered at $1525^{\circ} \mathrm{C}$ is 4.71 and 0.002 respectively. The error in dielectric properties measurement at the radio frequency for $\varepsilon_{\mathrm{r}}$ and tan $\delta$ is $1 \%$. The mineral $\mathrm{Al}_{2} \mathrm{SiO}_{5}$ possess low dielectric constant and low loss at $1 \mathrm{MHz}$. The sillimanite $\left(\mathrm{Al}_{2} \mathrm{SiO}_{5}\right)$ mineral is difficult to densify by sintering at $1525^{\circ} \mathrm{C}$ and further increase

in temperature convert the sillimanite to mullite. The sillimanite sintered at $1525^{\circ} \mathrm{C}$ has a density of 2 $\mathrm{g} / \mathrm{cm}^{3}$. However, the theoretical density of sillimanite is $3.1 \mathrm{~g} / \mathrm{cm}^{3}$ (calculated from the XRD data in the present study). The mineral sillimanite contains small amount of different impurity phases/substitutions and hence there can be differences in the theoretical as well as experimental densities of samples from different localities. In the present case, the evaluation of percentage density calculation is difficult due to presence of quartz $\left(\mathrm{SiO}_{2}\right)$ as secondary phase in the raw sillimanite. Hence the sillimanite is densified by cold sintering process using $\mathrm{NaCl}$. The XRD pattern of sillimanite-sodium chloride $\left(\mathrm{Al}_{2} \mathrm{SiO}_{5}-\mathrm{NaCl}\right)$ composites cold sintered at $120^{\circ} \mathrm{C}$ is shown in Fig. 3. The peaks of sillimanite $\left(\mathrm{Al}_{2} \mathrm{SiO}_{5}\right)$ (JCPDS file no. 220018), $\mathrm{NaCl}$ (JCPDSfileno.77-2064), quartz ( $\mathrm{SiO}_{2}$ ) (JCPDS file no.89-8934) are identified and indexed in the

XRD. It should be noted that there is no reaction between $\mathrm{Al}_{2} \mathrm{SiO}_{5}$ and $\mathrm{NaCl}$ by the cold sintering. The microstructure of the fractured surface of $\mathrm{Al}_{2} \mathrm{SiO}_{5}-\mathrm{NaCl}$ composite cold sintered at $120^{\circ} \mathrm{C}$ is shown in Fig. 4 .

The densification of $\mathrm{Al}_{2} \mathrm{SiO}_{5}$ ceramics with the aid of $\mathrm{NaCl}$ is evident from the microstructure. Fig. 4 (a) shows the microstructure of fractured surface and Fig. 4 (b) is the backscattered image of $\mathrm{Al}_{2} \mathrm{SiO}_{5}-\mathrm{NaCl}$ composite cold sintered at $120^{\circ} \mathrm{C}$. The SEM pictures do not show additional secondary phases other than 
$\mathrm{Al}_{2} \mathrm{SiO}_{5}$ and $\mathrm{NaCl}$. Here the densification of $\mathrm{Al}_{2} \mathrm{SiO}_{5}$ is promoted by the grain growth with the aid of pressure and temperature.

The room temperature FT-IR spectrum of $\mathrm{Al}_{2} \mathrm{SiO}_{5}-\mathrm{NaCl}$ composite is shown in Fig. 5. No peaks corresponding to water is identified in the FT-IR spectrum, which indicates that there is no residual water in the cold sintered sample. The peak around $1177 \mathrm{~cm}^{-1}$ corresponds to the characteristic peak of sillimanite which is assigned to the Al-O stretching vibrations [6]. The band position at $891 \mathrm{~cm}^{-1}$ is attributed to the symmetric stretching of $\mathrm{Si}-\mathrm{O}$ bond, $808 \mathrm{~cm}^{-1}$ corresponds to the antisymmetric bending, deformation of Si-O-Si and $697 \mathrm{~cm}^{-1}$ antisymmetric, bending, deformation Si O Si; Al1 translations [30,31]

The variation of dielectric properties of cold sintered $\mathrm{NaCl}$ at the radio frequency in the range $10 \mathrm{kHz}-1 \mathrm{MHz}$ is shown in Fig. 6(a). The dielectric constant and dielectric loss at $1 \mathrm{MHz}$ for $\mathrm{NaCl}$ is 5.88 and 0.009 respectively. Fig. 6 (b) shows the radio frequency dielectric properties of $\mathrm{Al}_{2} \mathrm{SiO}_{5}-\mathrm{NaCl}$ composite cold sintered at $120^{\circ} \mathrm{C}$. The $\varepsilon_{\mathrm{r}}$ and tan $\delta$ of the $\mathrm{Al}_{2} \mathrm{SiO}_{5}-\mathrm{NaCl}$ composite is 5.37 and 0.005 respectively. The addition of $\mathrm{NaCl}$ influences the dielectric properties of the $\mathrm{Al}_{2} \mathrm{SiO}_{5}$. The water solubility nature of the sintering aid $\mathrm{NaCl}$ used for the present study enables dissolution - precipitation which is a pre-requisite condition for the cold sintering process with the help of sufficient temperature and pressure.

The microwave dielectric properties of bulk $\mathrm{Al}_{2} \mathrm{SiO}_{5}$ sintered at $1525^{\circ} \mathrm{C}, \mathrm{NaCl}$ and $\mathrm{Al}_{2} \mathrm{SiO}_{5}-\mathrm{NaCl}$ cold sintered at $120^{\circ} \mathrm{C}$ is given in Table 1 . The mineral $\mathrm{Al}_{2} \mathrm{SiO}_{5}$ possess low dielectric constant with excellent $Q_{u} \times f$ value $(41,800) \mathrm{GHz}$. The temperature coefficient of resonant frequency of $\mathrm{Al}_{2} \mathrm{SiO}_{5}$ is obtained as $-17 \mathrm{ppm} /{ }^{\circ} \mathrm{C}$. The dielectric properties of the mineral indicate the possibility of use in microwave applications. The low dielectric constant of sillimanite provides the advantage of fast signal propagation when used for practical applications [32]. The $\mathrm{NaCl}$ sintering aid in the present work cold sintered at $120^{\circ} \mathrm{C}$ has $\varepsilon_{\mathrm{r}}=5.22(\sim 15.5 \mathrm{GHz})$ with $\mathrm{Q}_{u} \times f=12,000 \mathrm{GHz}$ and $\tau_{f}=-36 \mathrm{ppm} /{ }^{\circ} \mathrm{C}$. The $\mathrm{Al}_{2} \mathrm{SiO}_{5}-\mathrm{NaCl}$ composite has $\varepsilon_{\mathrm{r}}$ of 4.52 with $\mathrm{Q}_{u} \times f=22,350$ $\mathrm{GHz}$ with $\tau_{f}=-24 \mathrm{ppm} /{ }^{\circ} \mathrm{C}$. Compared to the bulk $\mathrm{Al}_{2} \mathrm{SiO}_{5}$, the $\mathrm{Q}_{u} \times f$ value is found to be decreased with the addition of $\mathrm{NaCl}$. But the addition of $\mathrm{NaCl}$, the densification of the $\mathrm{Al}_{2} \mathrm{SiO}_{5}$ is improved by employing the CSP process. The value of $\tau_{f}$ which is a measure of drift of resonant frequency with respect to temperature and low negative value in the present case indicates that the composite can be fruitfully used for microwave applications. Since $\mathrm{NaCl}$ is a hygroscopic material, for practical applications the composite can be coated or encapsulated with low loss plastic materials or silicone rubber. According to the rule of mixtures,

$$
\varepsilon_{\mathrm{c}}=\mathrm{V}_{1} \varepsilon_{1}+\mathrm{V}_{2} \varepsilon_{2}
$$

where $\varepsilon_{\mathrm{c}}$ is the dielectric constant of the $\mathrm{Al}_{2} \mathrm{SiO}_{5}-\mathrm{NaCl}$ composite, $\mathrm{V}_{1}$ and $\mathrm{V}_{2}$ are the volume fractions of $\mathrm{Al}_{2} \mathrm{SiO}_{5}$ and $\mathrm{NaCl}, \varepsilon_{1}$ and $\varepsilon_{2}$ are the corresponding dielectric constants. The dielectric constant obtained from the theoretical calculation of dielectric constant using the rule of mixtures is found to be 4.63 which are very close to the experimental value (see Table 1 ).

\section{Conclusions}

The feasibility of the cold sintering process in the densification of the naturally occurring mineral $\mathrm{Al}_{2} \mathrm{SiO}_{5}$ is successfully demonstrated in the present work. Compared to the conventional ceramic route, $\mathrm{Al}_{2} \mathrm{SiO}_{5} \mathrm{can}_{\text {be }}$ easily densified using the CSP. The structural analysis reveals the fact that there is no impurity phase in the composite $\mathrm{Al}_{2} \mathrm{SiO}_{5}-\mathrm{NaCl}$ composite. The cold sintered-composite has $\varepsilon_{\mathrm{r}}=5.37$ and tan $\delta$ of the order of $10^{-3}$ at $1 \mathrm{MHz}$. The microwave dielectric properties of the composite are $\varepsilon_{r}=4.52, \mathrm{Q}_{u} \times f=22,350 \mathrm{GHz}$ with $\tau_{\mathrm{f}}=-24$ $\mathrm{ppm} /{ }^{\circ} \mathrm{C}$.

\section{Acknowledgements}


Induja. I. J is grateful to the Kerala State Council for Science, Technology and Environment (KSCSTE) Kerala, India for the award of Research Fellowship. The authors are thankful to Dr. P. Prabhakar-Rao, Mr. Prithviraj for extending the XRD facility and Dr. Ratheesh. R, CMET, Thrissur for SEM images.

\section{References}

[1] K. Zhang, L. Yuan, Y. Fu, C. Yuan, W. Li, Microwave dielectric properties ofAl2O3ceramics co-doped with MgO and Nb2O5, J. Mater. Sci. Mater. Electron.26 (2015) 6526-6531.

[2] K.M. Manu, C. Karthik, L.C. Leu, K.A. Lazar, R. Ubic, M.T. Sebastian, Crystalstructure and microwave dielectric properties of LiRE9(SiO4)6O2ceramics(RE $=\mathrm{La}, \mathrm{Pr} \mathrm{Nd}, \mathrm{Sm}, \mathrm{Eu}, \mathrm{Gd}$, and Er), J. Am. Ceram. Soc. 96 (2013) 1504-1511.

[3] M.T. Sebastian, H. Jantunen, Low loss dielectric materials for LTCCapplications: a review, Int. Mater. Rev. 53 (2008) 57-90.

[4] H. Ohsato, M. Terada, I. Kagomiya, K. Kawamura, K.I. Kakimoto, E.S. Kim,Sintering conditions of cordierite for Microwave/Millimeter wave dielectrics,IEEE Trans. Ultrason. Ferroelectr. Freq.Control 55 (2008) 10811085.

[5] S. Yugeswaran, M. Vijay, K. Suresh, P.V. Ananthapadmanabhan, Z. Karoly, J.Szepvolgyi, Synthesis of mullite from sillimanite dissociation throughtransferred arc plasma torch, Int. J. Miner. Process. 99 (2011) 54-60.

[6] A. Tomba, M.A. Camerucci, G. Urretavizcaya, A.L. Cavalieri, M.A. Sainz, A.Caballero, Elongatedmullite crystals obtained from high temperaturetransformation of sillimanite, Ceram. Int. 25 (1999) 245-252.

[7] J.K. Winter, S. Ghose, Thermal expansion and high-temperature crystalchemistry of the Al2SiO5polymorphs, Am. Mineral. 64 (1979) 573-586.

[8] H. Yang, R.M. Hazen, L.W. Finger, C.T. Prewitt, R.T. Downs, Compressibility andcrystal structure of sillimanite Al2SiO5at high pressure, Phys. Chem. Miner.25 (1997) 39-47.

[9] W.H. Taylor, The structure of sillimanite and mullite, Z. Kristallogr 71 (1928)205-218.

[10] W.A. Deer, R.A. Howie, J. Zussman, Rock-Forming Minerals: Orthosilicates,Vol. 1A, The Geological Society, 1997.

[11] S. Tripathi, G. Banerjee, Synthesis and mechanical properties of mullite frombeach sand sillimanite: effect of TiO2, J. Eur. Ceram. Soc. 18 (1998) 2081-2087.

[12] S.S. Srikant, S.K. Singh, P.S. Mukherjee, R.B. Rao, Value addition to redsediment placer sillimanite using microwave energy and in depth structuraland morphological characterization of mullite, J. Miner. Mater. Charact. Eng.11 (2012) 1055-1062.

[13] J.P. Hirth, L. Kubin, Dislocations in Solids, The 30th Anniversary Volume,Elsevier, UK, 2010.

[14] S. Aryal, P. Rulis, W.Y. Ching, Density functional calculations of the electronicstructure and optical properties of aluminosilicate polymorphs (Al2SiO5), Am.Miner. 93 (2008) 114-123.

[15] H. Kahari, M. Teirikangas, J. Juuti, H. Jantunen, Dielectric properties of lithiummolybdate ceramic fabricated at room temperature, J. Am. Ceram. Soc. 97(2014) 3378-3379.

[16] H. Kahari, M. Teirikangas, J. Juuti, H. Jantunen, Improvements andmodifications to room temperature fabrication method for dielectricLi2MoO4 ceramics, J. Am. Ceram. Soc. 98 (2015) 687-689. 
[17] H. Kahari, M. Teirikangas, J. Juuti, H. Jantunen, Room-temperature fabricationof microwave dielectric Li2MoO4-TiO2composite ceramics, Ceram. Int. 42(2016) 11442-11446.

[18] C.A. Randall, J. Guo, H. Guo, A. Baker, M.T. Lanagan, Cold Sintering Ceramicsand Composites, US Provisional Patent Application, (2015) 62/234 389.

[19] H. Guo, J. Guo, A. Baker, C.A. Randall, Hydrothermal-assisted cold sinteringprocess: a new guidance for low-temperature ceramic sintering, ACS Appl.Mater. Interfaces 8 (2016) 20909-20915.

[20] J. Guo, S.S. Berbano, H. Guo, A.L. Baker, M.T. Lanagan, C.A. Randall, Coldsintering process of composites: bridging the processing temperature gap ofceramic and PolymerMaterials, Adv. Funct. Mater. 26 (2016) 7115-7121.

[21] N.J. Lóh, L. Simão, C.A. Faller, A. De Noni Jr., O.R.K. Montedo, Review article. Areview of two-step sintering for ceramics, Ceram. Int. 42 (2016) 12556-12572.

[22] J. Guo, H. Guo, A.L. Baker, M.T. Lanagan, E.R. Kupp, G.L. Messing, C.A. Randall,Cold sintering: a paradigm shift for processing and integration of ceramics,Angew. Chem. Int. Ed. 55 (2016) 11457-11461.

[23] J. Guo, S.S. Berbano, H. Guo, A.L. Baker, M.T. Lanagan, C.A. Randall, Coldsintering process of composites: bridging the processing temperature gap ofceramic and polymer materials, Adv. Funct. Mater. 26 (2016) 7115-7121.

[24] A. Baker, H. Guo, H.J. Guo, C. Randall, Utilizing the cold sintering process forflexible- printable electroceramic device fabrication, J. Am. Ceram. Soc. 99(2016) 3202-3204.

[25] H. Guo, A. Baker, J. Guo, C.A. Randall, Cold sintering process: a novel techniquefor low-temperature ceramic processing of ferroelectrics, J. Am. Ceram. Soc.(2016), http://dx.doi.org/10.1111/jace.14554.

[26] H. Guo, J. Guo, A. Baker, C.A. Randall, Hydrothermal-assisted cold sinteringprocess: a new guidance for low-temperature ceramic sintering, ACS Appl.Mater. Interfaces 8 (2016) 20909-20915.

[27] H. Guo, J. Guo, A. Baker, C.A. Randall, Cold sintering process for ZrO2-basedceramics: significantly enhanced densification evolution in yttria-dopedZrO2, J. Am. Ceram. Soc. (2016), http://dx.doi.org/10.1111/jace.14593.

[28] S. Funahashi, J. Guo, H. Guo, K. Wang, A.L. Baker, K. Shiratsuyu, C.A. Randall,Demonstration of the cold sintering process study for the densification andgrain growth of $\mathrm{ZnO}$ ceramics, J. Am. Ceram. Soc. (2016), http://dx.doi.org/10.1111/jace.14617.

[29] P.M. Ihlen, Utilisation of sillimanite minerals, their geology, and potentialoccurrences in Norway -an overview, NGU-Bull. 436 (2000) 113-128.

[30] M. Lodzinski, R. Wrzalik, M. Sitarz, Micro-Raman spectroscopy studies ofsome accessory minerals from pegmatites of the SowieMts andStrzegom-Sobótka massif, J. Mol. Struct. 744-747 (2005) 1017-1026.

[31] K. lishi, E. Salje, C. Werneke, Phonon spectra and rigid-ion model calculationson andalusite, Phys. Chem. Miner. 4 (1979) 73-188.

[32] M.T. Sebastian, Dielectric Materials for Wireless Communication, Elsevier,Oxford, 2008. 


\section{Table and Figures}

Table 1. Microwave dielectric properties of bulk $\mathrm{Al}_{2} \mathrm{SiO}_{5}$ sintered at $1525^{\circ} \mathrm{C}, \mathrm{NaCl}$ and $\mathrm{Al}_{2} \mathrm{SiO}_{5}-\mathrm{NaCl}$ composite cold sintered at $120^{\circ} \mathrm{C}$.

\begin{tabular}{|l|l|l|l|l|}
\hline Material & $\boldsymbol{\varepsilon}_{\mathrm{r}} \pm \mathbf{2 \%}$ (Hakki) & $\begin{array}{l}\left(\mathbf{Q}_{\mathbf{u}} \times \mathbf{f}\right) \pm \mathbf{2 \%}(\mathbf{G H z}) \\
\text { (Cavity) }\end{array}$ & $\begin{array}{l}\mathbf{\tau}_{\mathbf{f}} \pm \mathbf{2 \%} \\
\left(\mathbf{p p m} /{ }^{\circ} \mathbf{C}\right)\end{array}$ & $\begin{array}{l}\text { Density } \pm \mathbf{1 \%} \\
\left(\mathbf{g} / \mathbf{c m}^{\mathbf{3}}\right)\end{array}$ \\
\hline $\mathrm{Al}_{2} \mathrm{SiO}_{5}\left(\right.$ Sintered at $\left.1525^{\circ} \mathrm{C}\right)$ & $4.43(\sim 16 \mathrm{GHz})$ & 41,800 & -17 & 2.00 \\
\hline $\mathrm{NaCl}_{\left(\mathrm{CSP} \text { at } 120^{\circ} \mathrm{C}\right)}$ & $5.22(\sim 15.5 \mathrm{GHz})$ & 12,000 & -36 & 2.10 \\
\hline $\mathrm{Al}_{2} \mathrm{SiO}_{5}-\mathrm{NaCl}\left(\mathrm{CSP}\right.$ at $\left.120^{\circ} \mathrm{C}\right)$ & $4.52(\sim 17 \mathrm{GHz})$ & 22,350 & -24 & 2.39 \\
\hline
\end{tabular}

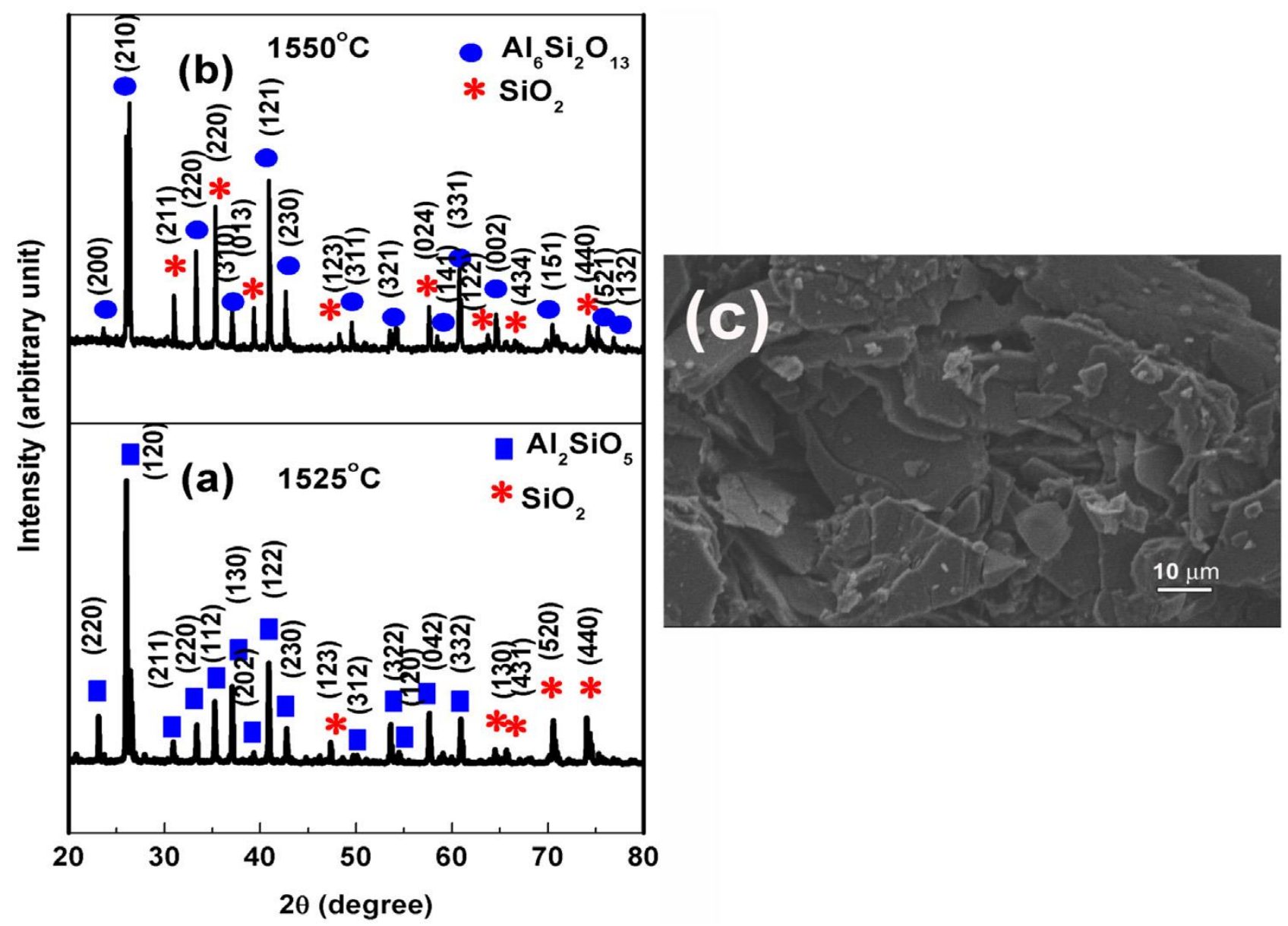

Fig. 1. (a) XRD pattern of bulk sillimanite sintered at (a) $1525^{\circ} \mathrm{C}$ and (b) $1550^{\circ} \mathrm{C}$ and (c) microstructure of fractured surface of sillimanite sintered at $1525^{\circ} \mathrm{C}$ using the conventional solid state ceramic method. 


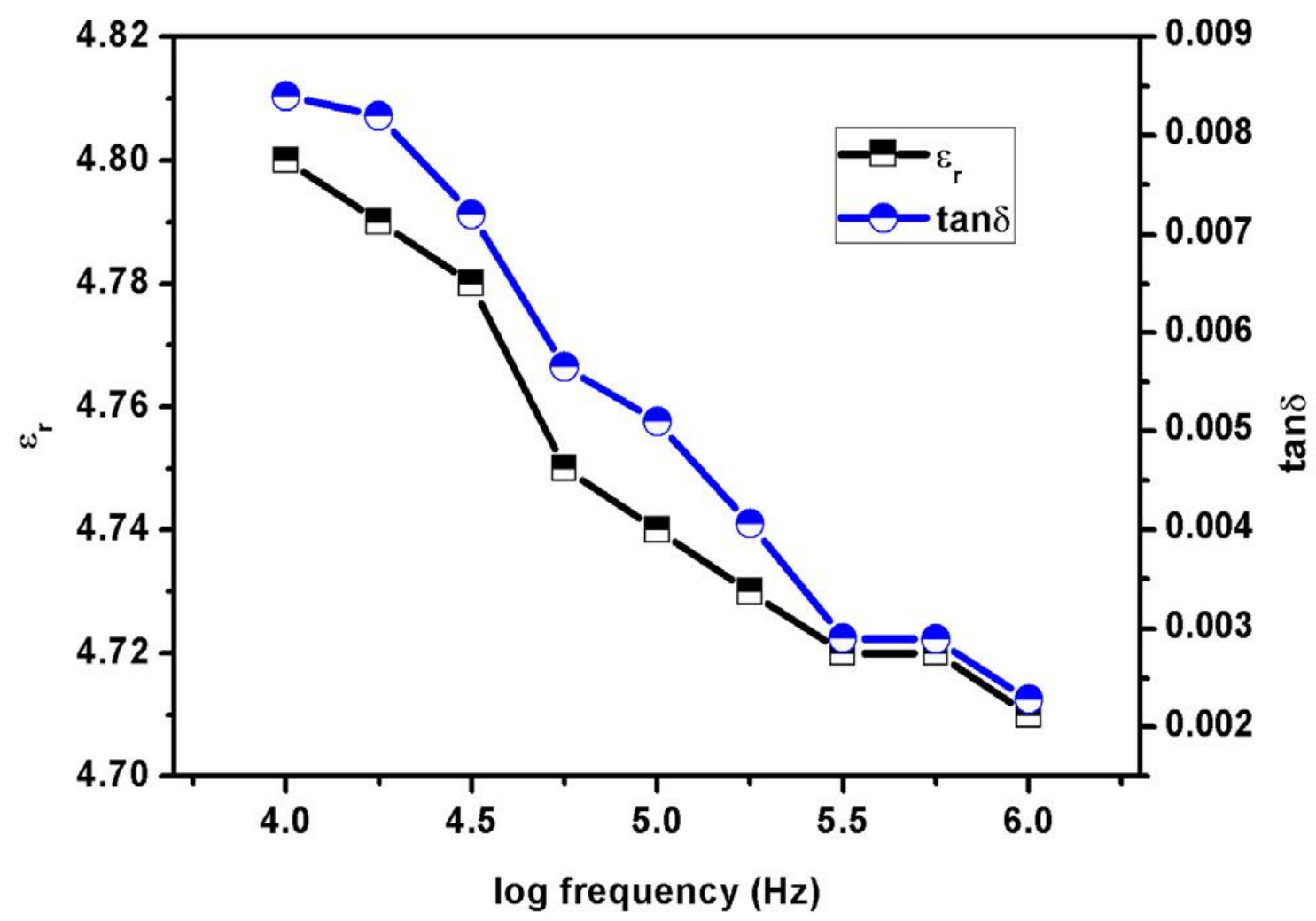

Fig. 2. Variation of dielectric properties with radio frequency of bulk $\mathrm{Al}_{2} \mathrm{SiO}_{5}$ sintered using conventional ceramic route at $1525^{\circ} \mathrm{C}$.

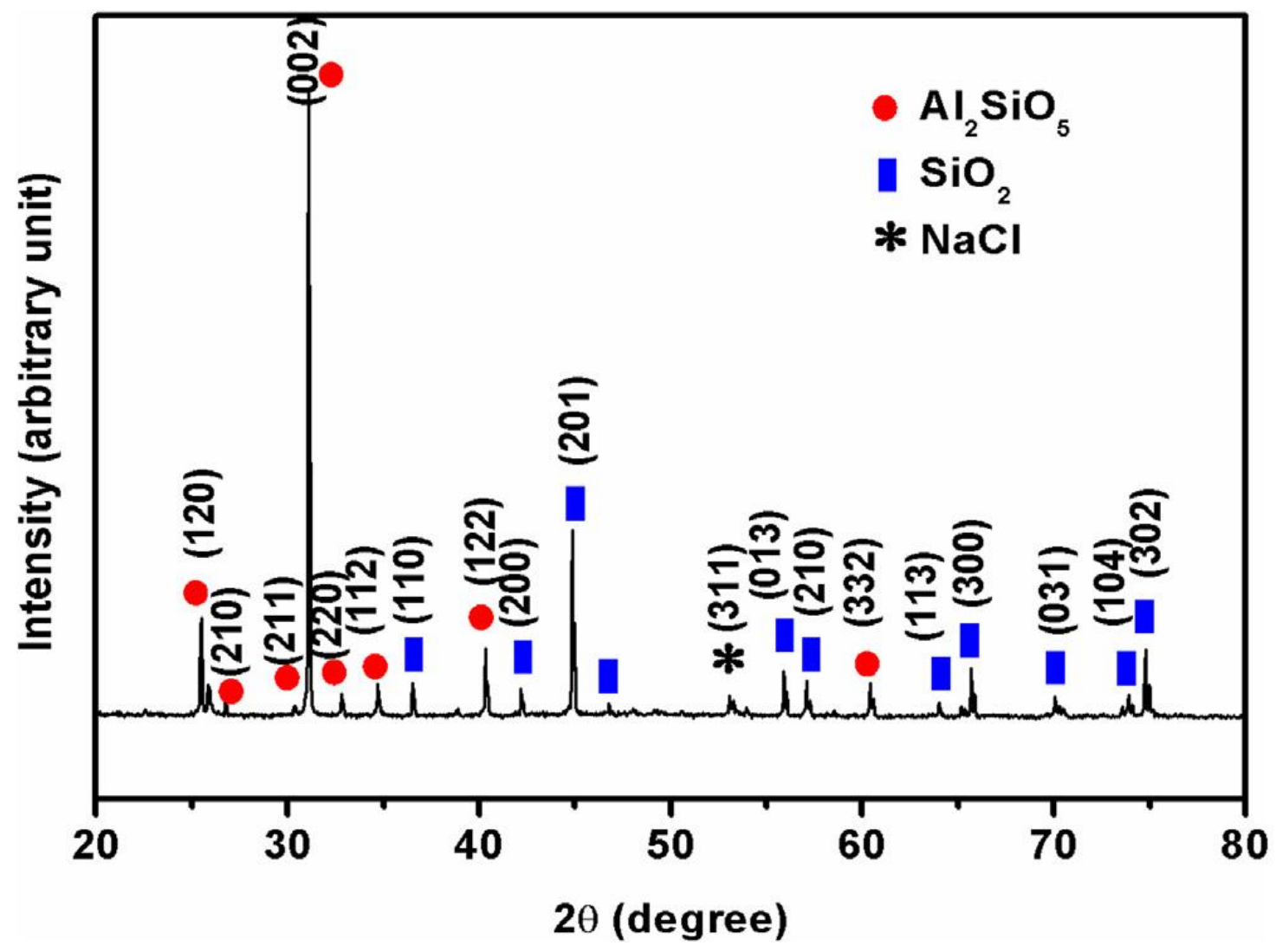

Fig. 3. XRD pattern of $\mathrm{Al}_{2} \mathrm{SiO}_{5}-\mathrm{NaCl}$ composite cold sintered at $120^{\circ} \mathrm{C}$. 

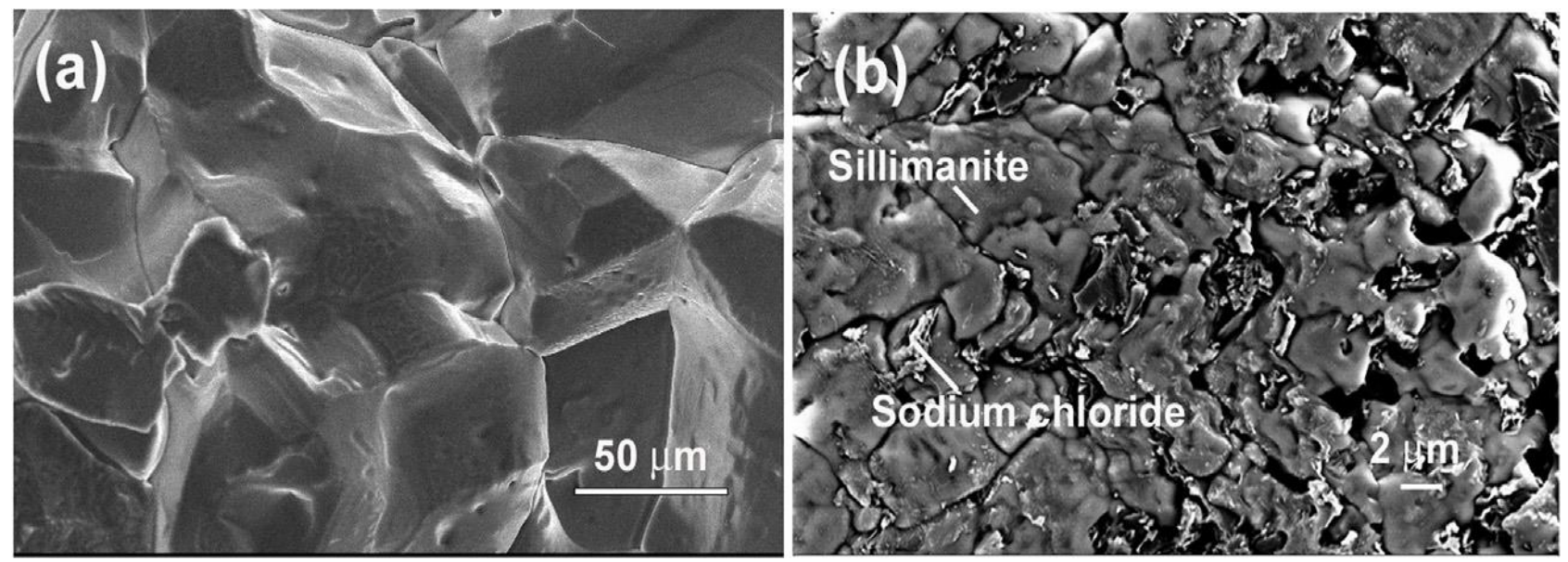

Fig. 4. (a) microstructure of the fractured surface and (b) backscattered image of $\mathrm{Al}_{2} \mathrm{SiO}_{5}-\mathrm{NaCl}$ cold sintered at $120^{\circ} \mathrm{C}$.

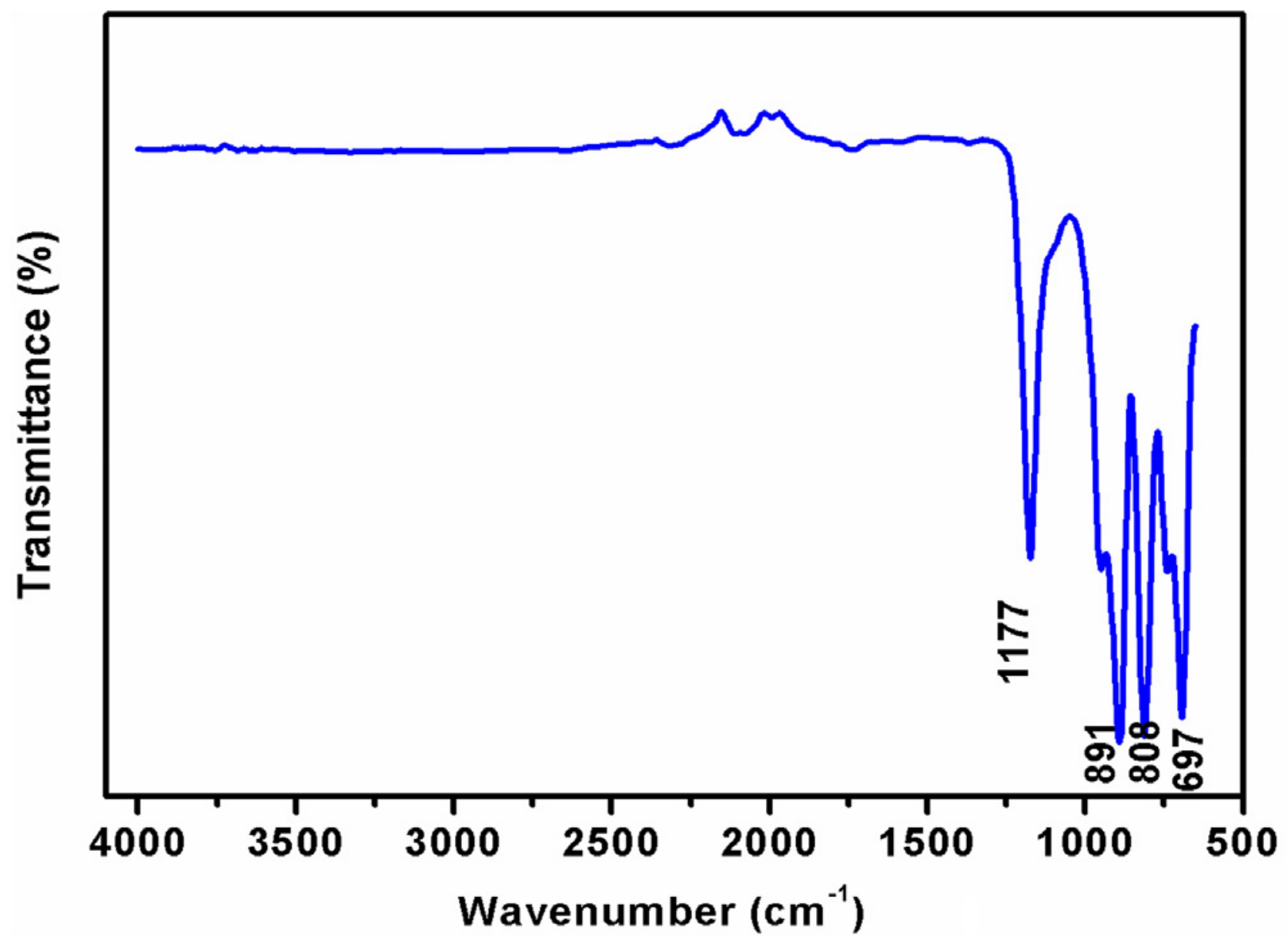

Fig. 5. Room temperature FT-IR spectrum of $\mathrm{Al}_{2} \mathrm{SiO}_{5}-\mathrm{NaCl}$ composite cold sintered at $120^{\circ} \mathrm{C}$. 

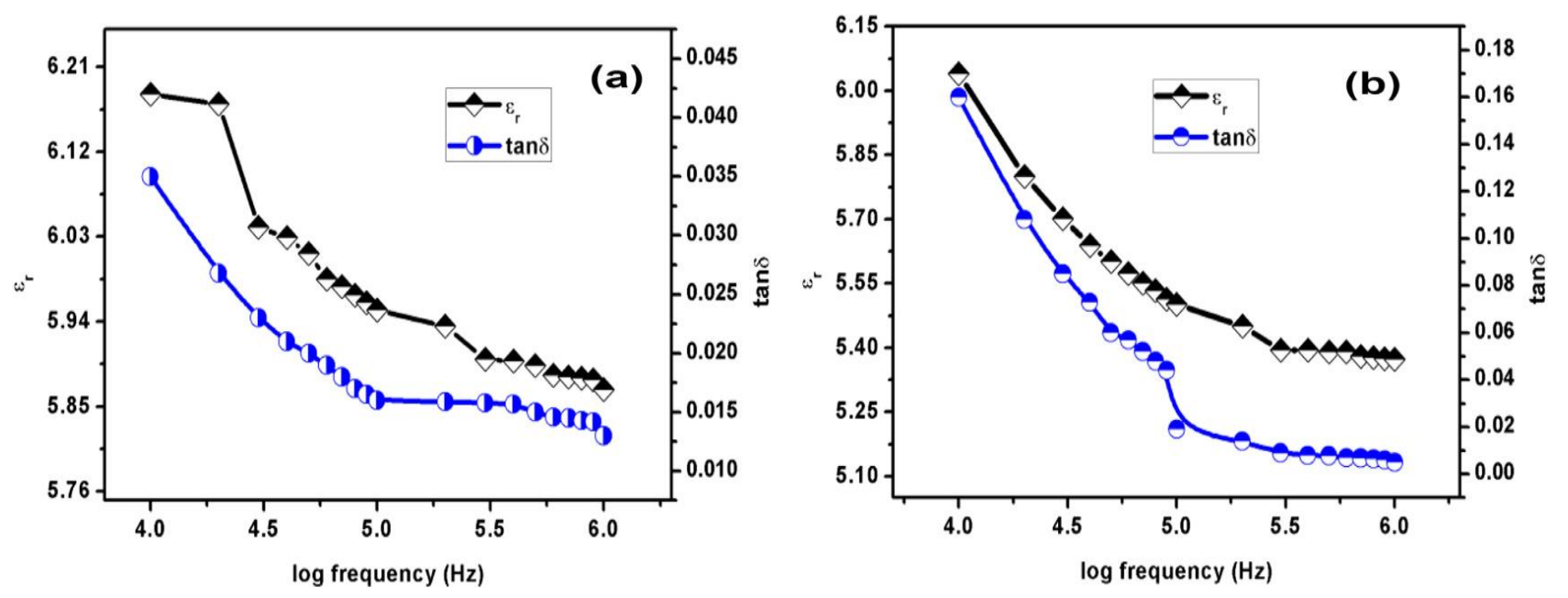

Fig. 6. Variation of dielectric properties with radio frequency of (a) pure $\mathrm{NaCl}$ (b) $\mathrm{Al}_{2} \mathrm{SiO}_{5}-\mathrm{NaCl}$ composite cold sintered at $120^{\circ} \mathrm{C}$. 